Article

\title{
Smallholder Forestry in the Western Amazon: Outcomes from Forest Reforms and Emerging Policy Perspectives
}

\author{
Pablo Pacheco ${ }^{1, *}$, Elena Mejía ${ }^{2}$, Walter Cano ${ }^{3}$ and Wil de Jong ${ }^{4}$ \\ Center for International Forestry Research (CIFOR), Jalan CIFOR, Situ Gede, Bogor Barat 16115, Indonesia \\ Independent, Calle Luis Calisto N49-21, Quito, EC170104, Ecuador; elenatura@gmail.com \\ 3 Independent, Rua Jose Kairala 113, Brasileia, Acre, CP69932000, Brazil; walter.cano.cardona@gmail.com \\ 4 Center for Integrated Area Studies, Kyoto University, 46 Chimoadachichou Sakyoku, Kyoto 6068501, Japan; \\ dejongwil@gmail.com \\ * Correspondence: p.pacheco@cgiar.org; Tel.: +62-251-8622-622; Fax: +62-251-8622-100
}

Academic Editor: Timothy A. Martin

Received: 20 May 2016; Accepted: 25 August 2016; Published: 31 August 2016

\begin{abstract}
The forest reforms unfolding during the last two decades in the western Amazon have embraced policy regimes founded on the principles of sustainable forest management. The policy frameworks adopted for smallholder forestry aimed to clarify forest rights including those of the indigenous people and smallholders, support the adoption of sustainable forest management and put a system in place to assure a legal timber supply. The emerging forest policy regimes have significantly shaped who has access to the forest, how the forest resources are used and the benefits that are utilized. We argue that forest reforms have not addressed some critical constraints facing smallholders in managing their forests either individually or collectively. Informal timber extraction persists with contradictory effects on smallholders and forests. Local participants continue to make a significant contribution in meeting a growing demand for timber through vigorous market networks that combine legal and illegal sources of timber supply. Some recent changes to forest policy frameworks emphasize approaches towards additional integrated forest management, simplification of regulations and incentives for improved forest management. We critically reflect on the scope, implementation and expected outcomes of these policy frameworks.
\end{abstract}

Keywords: Amazon; forest management; forest policy; forest governance; smallholders; Bolivia; Ecuador; Peru

\section{Introduction}

Large portions of the territories of Bolivia, Ecuador and Peru are covered with tropical and subtropical forests. The countries make up a large part of the western Amazon. Local groups include indigenous people, non-indigenous long term and more recent residents of rural settlements and smallholders (We will use the term "smallholders" throughout this text to refer to individual landholders, indigenous and non-indigenous communities. Occasionally, where it is appropriate we specifically refer to any of these three groups). All of these groups depend, in different degrees, on the forests to meet their daily livelihood needs and extract forest products, including timber, to add to their monetary income. Nowadays forest based smallholders contribute significantly to the domestic and international timber supply. How forests contribute to smallholder incomes and livelihood strategies is influenced by the rules that regulate forest use and management; and the market conditions for forest products mainly because rules and markets do shape the dynamics of the forestry sector in general. 
Bolivia, Ecuador and Peru implemented forest policy reforms—or forest reforms—-from the mid- to late-1990s, inspired by sustainable forest management (SFM) principles [1]. The new forestry regimes in each country shared three objectives: (i) stimulate smallholder forestry through wide reaching land and forest ownership changes; (ii) improve forest management practices by all forest users; and (iii) reduce unauthorized practices along the timber value chain through timber legality verification.

Our paper examines how the forest reforms in the three countries currently influence smallholder forestry. We attempt to answer the following questions: What is the influence of tenure rights in stimulating smallholder forestry?; what are the main barriers preventing the adoption of SFM by smallholders?; and, why does unauthorized timber extraction persist among this group of forest users? These questions are at the center of the current debate on how to enhance the contribution of forests to smallholder livelihoods while at the same time securing the provision of forest ecosystem services. With this paper we hope to contribute to the broader efforts in order to improve land use governance in contributing to rural development [2] and align those efforts with wider efforts for forest-based contributions to climate change mitigation and adaptation [3].

We selected Bolivia, Ecuador and Peru because they hold an important portion of Western Amazon and have a shared history of land occupation in the Amazon. They also share policy and regulatory frameworks inspired by common development paradigms. We undertook a literature review and carried out interviews between July 2011 and October 2014 in the department of Pando in Bolivia, the provinces of Napo and Orellana in Ecuador and the departments of Loreto, Ucayali and Madre de Dios in Peru. The interviews were part of a comparative study on the influence of forest regulations on timber markets and smallholder livelihoods, implemented by CIFOR and partners. Interviewees included staff of state agencies, forestry projects and NGOs, timber intermediaries and local authorities. Reports with detailed descriptions of the methodologies are available for Bolivia [4], Ecuador [5] and Peru [6].

The paper contains five parts. Section 2 describes smallholder forestry and its contribution to broader forestry sector developments in the Amazon regions of the three countries. Section 3 summarizes the relevant legal and policy evolutions over time and emerging policy views. Section 4 discusses the implications of forest reforms for smallholder forestry emphasizing the allocation of tenure rights, forest management systems and timber markets. The last section presents the discussion and conclusions.

\section{Smallholders and Forest Use in Western Amazon}

Forests cover 49 million ha in Bolivia, 11 million ha in Ecuador and 73 million ha in Peru (Figure 1). Production forests in Bolivia and Peru are given out as forest concessions, of which there are 3.8 million ha in Bolivia and 7.6 million ha in Peru. Ecuador has no forest concessions (Table 1). Indigenous and non-indigenous people control a significant amount of forest but part of it overlaps with protected areas. The contributions of forestry and smallholder forestry to the national economies in Bolivia, Ecuador and Peru vary. The historical processes of land occupation and infrastructure development in the Amazon, the trends of industrial forestry and wider sociopolitical dynamics account for the differences. The formal contribution of forests to total gross domestic product, mostly production and trade of timber is about 3\% in Bolivia, 2\% in Ecuador and 1\% in Peru [7]. 


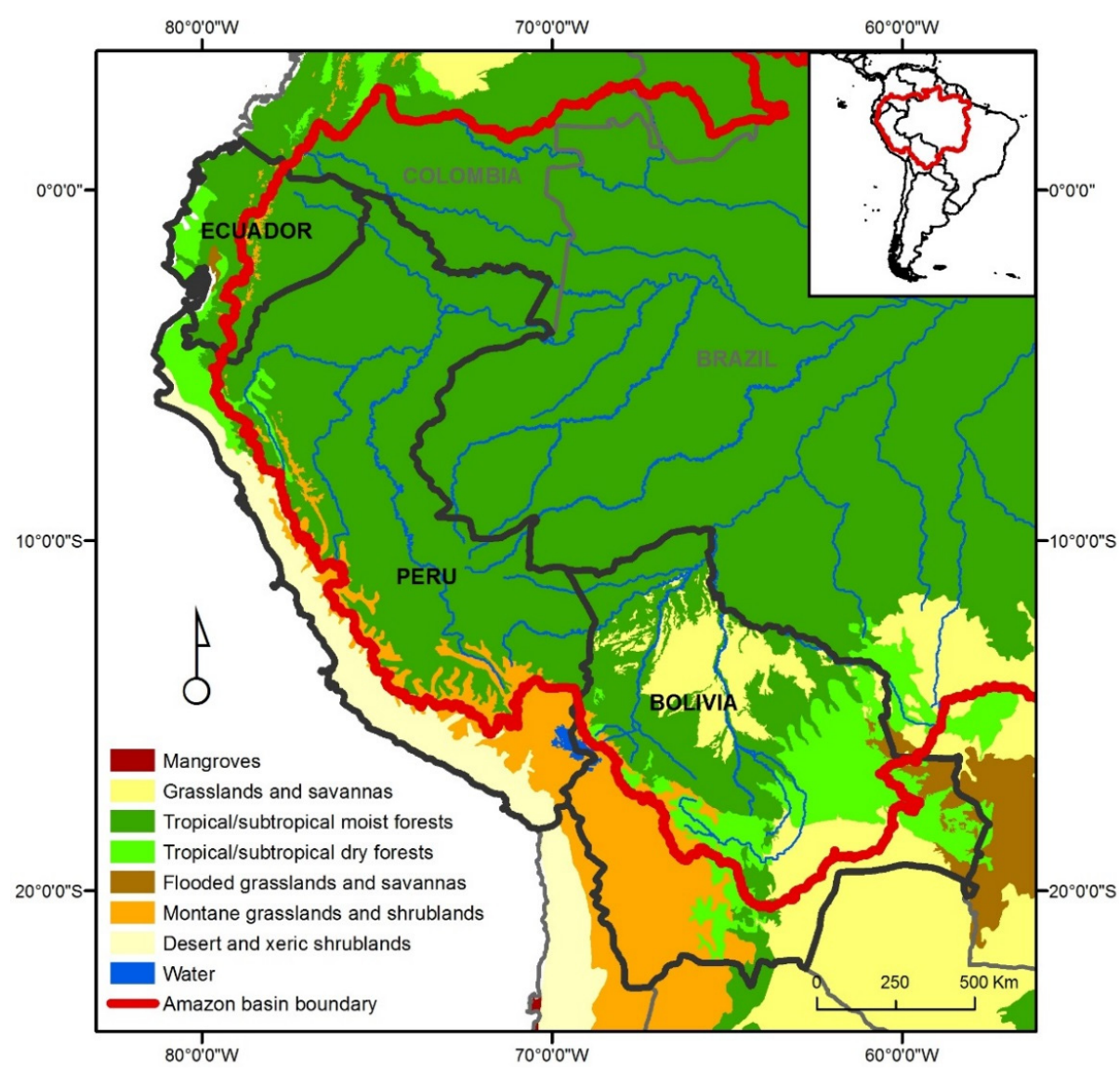

Figure 1. Biomes in Bolivia, Ecuador and Peru. Source: Authors' mapping of data from WWF Ecoregions profile [8].

The actual contribution of forests to the livelihoods of local forest users (i.e., indigenous and non-indigenous communities, timber extractors, intermediaries, chainsaw millers) is important but difficult to quantify [9]. Forest resources contribute to meeting different local people's needs for food, firewood, materials for construction, among others. However, forests also provide important resources for commercial use, notably timber, with growing market demand due to urban expansion. In Bolivia and Peru, most of the timber supply originates from forests in the Amazon, which are abundant compared to the poorly developed plantations in these countries. In contrast, Ecuador produces much more timber in plantations than Peru and Bolivia [10]. Timber from plantations is complemented with timber from the country's Amazon native forests [11]. A major portion of the timber from native forest extracted by smallholders in the three countries originates from the Amazon (Table 1).

Ecuador has a relatively well-developed industrial sector that sources its raw material for briquettes and plywood from timber plantations located in the highlands and coastal zones [12]. In addition, an important small-scale artisanal sector in the Ecuadorian Amazon involves smallholders who supply timber for construction and furniture manufacturing to the main urban centers [5]. Peru has an important timber industry, which depends on timber from Amazonian smallholder lands and forest concessions. Because of a more stringent implementation of forest regulations, in recent years many concessions have been returned to the state but timber is still widely harvested illegally $[13,14]$. Amazonian timber supplies the construction sector and the domestic manufacturing industry in the main cities [15,16]. In Bolivia, most of the timber originates from the Amazon and it supplies domestic markets and export markets. The domestic markets for timber production in Bolivia, Ecuador and Peru, mainly in the furniture and construction sectors, are likely to continue to expand due to an increasing demand associated with a growing urban population [17]. 
Table 1. Selected Information on the Forestry Sector in Bolivia, Ecuador and Peru.

\begin{tabular}{|c|c|c|c|}
\hline Key Select Indicators & Bolivia & Ecuador & Peru \\
\hline Total forest area (million ha) & $49.0^{\mathrm{a}}$ & $11.0^{\mathrm{b}}$ & $73.0^{\mathrm{c}}$ \\
\hline $\begin{array}{l}\text { Average annual domestic market consumption, 2008-2012 } \\
\text { (roundwood equivalent in million } \mathrm{m}^{3} \text { ) }\end{array}$ & $0.8^{\mathrm{d}}$ & $2.6^{\mathrm{e}}$ & $2.1^{\mathrm{f}}$ \\
\hline $\begin{array}{c}\text { Total area of state production forests allocated to timber and } \\
\text { non-timber forest concessions (million ha) }\end{array}$ & $3.8^{\mathrm{d}}$ & 0.0 & $7.6^{\mathrm{g}}$ \\
\hline Total land occupied by smallholders in the Amazon (million ha) & $20.7^{h}$ & $7.5^{\mathrm{i}}$ & 13.28 \\
\hline $\begin{array}{c}\text { Total area of forests under approved management plans for } \\
\text { timber for smallholders (million ha) }\end{array}$ & $0.59^{\mathrm{d}}$ & $0.16^{\mathrm{j}}$ & $0.03^{k}$ \\
\hline Production in native forests (million $\mathrm{m}^{3}$, average 2008-2012) & $1.1^{\mathrm{d}}$ & $0.2^{\mathrm{e}}$ & $1.6^{1}$ \\
\hline $\begin{array}{l}\text { Average contribution (\%) to timber supply by smallholders in the } \\
\qquad \text { Amazon, 2008-2012 }\end{array}$ & $84.0^{\mathrm{m}}$ & $35.0^{\mathrm{e}}$ & $22.0^{\mathrm{n}}$ \\
\hline $\begin{array}{l}\text { Small-scale forestry operations carried out without an approved } \\
\text { forest management plan }(\%)\end{array}$ & NA & $70.0^{\circ}$ & $80.0^{\mathrm{P}}$ \\
\hline
\end{tabular}

Notes: ${ }^{a}$ based on Killeen et al. [18]; ${ }^{\mathrm{b}}$ CORPEI [11]; ${ }^{\mathrm{c}}$ Ministerio del Ambiente [19]; ${ }^{\mathrm{d}}$ ABT [20]; ${ }^{\mathrm{e}}$ Ministerio del Ambiente [21]; ${ }^{\mathrm{f}}$ based on data from Ministerio de Agricultura [22]; ${ }^{\mathrm{g}}$ ITTO [23]; ${ }^{\mathrm{h}}$ taken from Pacheco and Benatti [24]; ${ }^{i}$ based on Añazco et al. [25]; ${ }^{j}$ based on FAO [26]; ${ }^{k}$ based on Presidencia del Consejo de Ministros [27]; ${ }^{1}$ based on data from Ministerio del Ambiente [13,22]; ${ }^{\mathrm{m}}$ authors' own estimate based on data from ABT [28] for 2010-2012; ${ }^{\mathrm{n}}$ based on authors' estimates with Instituto Nacional de Estadística e Informática (INEI) census data from 2007 and an average of $7 \mathrm{~m}^{3}$ per family, per year based on authors' data collected in 2013 and 2014 in Ucayali, Madre de Dios and Loreto; ${ }^{\circ}$ authors' estimates based on interviews with 129 households that carried out forestry operations (out of the 226 households interviewed from August 2011 to September 2012 in Napo Province and from February 2011 to July 2012 in Orellana province) see Mejía and Pacheco [5,24]; $\mathrm{p}$ based on OSINFOR [29].

Compared to Ecuador and Peru, the timber industry in Bolivia is relatively unimportant. In addition to meeting domestic demand, a few processing companies have specialized producing furniture for the export market. Bolivian timber is sourced from forest concessions and communal lands. Forest concessions granted in public production forests used to be significant in Bolivia and an important portion were under FSC certification. But small-scale timber extraction has expanded over time, while forest concessions have been reduced significantly since the late 2000s [30]. Timber exports have also declined and domestic markets constitute the main demand for timber production, which is also met by imports [31].

Smallholders occupy an important forest area in all three countries, yet the legal ownership of these lands vary. In Bolivia and Ecuador, smallholder communities have legal ownership over relatively large areas of forest but not so in Peru. Only a small portion of lands held by smallholder communities are under formal forest management plans, suggesting that most of the timber originating from smallholders' lands is harvested illegally. This is also suggested by the contributions of smallholders to the timber supply in Bolivia (84\%), Ecuador (35\%) and Peru (22\%) (Table 1). Other locals also engage in timber harvesting, including chainsaw operators and small operators. A variety of intermediaries channels this timber to the large timber producers or traders [32].

Smallholders adopt different forms and practices of forest management but their implications for forest composition and structure in the long term are not well known. Smallholder-based forest management may range from large-scale selective logging, particularly in indigenous lands in lowland Bolivia [32] to low-intensity harvesting in small-sized plots and chainsaw milling. The latter system is quite extensive in the Ecuadorian Amazon [5] and is also widely adopted in the Bolivian [4] and Peruvian Amazon [6]. There is no strong evidence to suggest that smallholder forest management is more destructive than the management practices following SFM principles [33].

In Ecuador, timber volumes extracted by smallholders in single operations without formal management plans tend to be lower than timber volumes extracted in single operations with 
management plans [34]. Formal timber operations are often organized by intermediaries who have the resources to obtain extraction permits, who want to maximize the volume extracted and from the most valuable species. Ecuadorean smallholders who operate without a management plan often choose soft species that require less labor and capital [10]. Small-scale logging and milling in northern La Paz in Bolivia and Pucallpa in Peru results in heavy logging of hard wood species, resulting in forest degradation [32]. Smallholders in Ecuador and Peru are increasingly logging timber species from forest regrowth [35]. In the Ecuadorian Amazon, swidden-fallow species such as Piptocoma discolor and Cordia alliodora are now commonly harvested [36] and sold in urban markets. In the Peruvian Amazon Guazuma crinita is harvested and used in coastal cities for the manufacture of prefabricated houses [37].

Timber however, is not the main source of income for smallholders or communities in the western Amazon [38]. Most smallholders who extract timber rely on a mix of subsistence and cash-income activities [39]. Only in a few cases is timber extraction the primary economic activity and mostly where development projects have encouraged communities to focus on commercial logging [40]. For example in the Ecuadorian Amazon, about 16\% of total smallholder income originates from timber extraction [5]. This portion is $38.8 \%$ in the Peruvian Amazon [41] and it ranges from $15 \%$ to $30 \%$ in the Bolivian Amazon [42]. Forest regulations implicitly assume that smallholders can dedicate sufficient attention to timber management. In many cases however, decisions about timber extraction are made by chainsaw operators and intermediaries, while smallholders make decisions on a broad portfolio of land and resource use, including agriculture and forest management see [43-45].

\section{Forest Reforms That Focus on Smallholder Forestry}

\subsection{First Wave of Forest Reforms}

The neo-liberal economic policies of the 1990s assigned a dominant role to external markets [46], including the national agricultural and manufacture sectors. State subsidies, price controls and tariffs for imports were suppressed [47]. Institutional conditions for biodiversity conservation concurred with support for agricultural expansion [48] but also with decentralizing decision-making at lower levels of government and expanding local participation [49]. External pressures from multilateral organizations and donors, improved planning and investment of public funds, addressed a growing demand from social groups for greater participation in decision-making [50]. Decentralization was implemented in Bolivia, Ecuador and Peru, with some variations in scope and pace.

In the forest sector, economic development and forest conservation goals fit well with the principles of SFM, while at the same time allowing the expansion of timber production to meet the demand from export markets. It was assumed the adoption of SFM could improve the economic benefits from forests and decrease the pressures from alternative land uses that resulted in forest conversion [51]. Reduced impact logging (RIL) techniques were expected to increase logging productivity and improved species inventory linked to harvesting and plans to diversify extraction of the lesser-known species [52]. Improving timber legality verification would reduce illegal operations and reduce unfair competition against legal timber [53]. FSC certification was actively promoted to reward SFM in large-scale commercial operations and later in smallholder timber operations [54]. In addition, greater social demands for land incubated the view that control by local participants over forests would also allow them to benefit from timber sales, while forests would still remain protected [55]. Yet, since state bureaucrats saw local communities and smallholders as unable to make efficient use of forests, they retained the command-and-control approach as a way of state agencies enforcing the adoption of SFM [56].

The pursuit of SFM triggered distinct policy processes to change the forestry laws in the three western Amazonian countries. Bolivia approved a new Forestry Law in 1996 and Peru followed in 2000. In Ecuador, new forest regulations were enacted in 2000. Table 2 presents the main forest policies related to these three policy goals. 
Table 2. Main Forest Policy Goals and Regulations in Bolivia, Ecuador and Peru.

\begin{tabular}{|c|c|c|c|}
\hline Policy Areas & Bolivia $^{\text {a }}$ & Ecuador $^{b}$ & Peru $^{c}$ \\
\hline \multicolumn{4}{|c|}{ Tenure rights for supporting smallholder forestry } \\
\hline $\begin{array}{l}\text { Forest tenure } \\
\text { rights for } \\
\text { different forest } \\
\text { users }\end{array}$ & $\begin{array}{l}\text { Exclusive rights for } \\
\text { indigenous people and } \\
\text { smallholders to use the } \\
\text { forests on their lands. }\end{array}$ & $\begin{array}{l}\text { Individual access rights to } \\
\text { forests recognized for } \\
\text { smallholders, and collective } \\
\text { tenure rights recognized for } \\
\text { indigenous communities. }\end{array}$ & $\begin{array}{l}\text { Indigenous collective rights } \\
\text { are recognized by the state, as } \\
\text { well as forest rights on } \\
\text { individual landholdings. }\end{array}$ \\
\hline \multicolumn{4}{|c|}{ Adoption of sustainable forest management } \\
\hline $\begin{array}{l}\text { Forest } \\
\text { management } \\
\text { regulations }\end{array}$ & $\begin{array}{l}\text { Commercial forest uses } \\
\text { require approval of FMPs } \\
\text { and AOPs. FMPs require the } \\
\text { elaboration of inventories } \\
\text { and censuses. } \\
\text { Non-commercial uses do not } \\
\text { require a plan. }\end{array}$ & $\begin{array}{l}\text { Simplified FMPs based on } \\
\text { rapid inventories and species } \\
\text { regulations are possible for } \\
\text { agroforestry and silvo-pastoral } \\
\text { systems and native forest for } \\
\text { non-mechanized } \\
\text { extraction operations. }\end{array}$ & $\begin{array}{l}\text { Commercial uses require an } \\
\text { FMP and AOP as the main } \\
\text { tools to achieve sustainable } \\
\text { forest management. } \\
\text { The logging of small volumes } \\
\text { of timber for sale is not } \\
\text { regulated but illegal. }\end{array}$ \\
\hline $\begin{array}{l}\text { Economic } \\
\text { incentives for } \\
\text { forest } \\
\text { management }\end{array}$ & $\begin{array}{l}\text { Differentiated forest fees, } \\
\text { with reduced fees for } \\
\text { smallholders over the total } \\
\text { forest area under } \\
\text { commercial use. }\end{array}$ & $\begin{array}{l}\text { Costs for the granting of } \\
\text { permits vary depending on the } \\
\text { type of mechanism used for } \\
\text { harvesting, the type of forest } \\
\text { formation and the } \\
\text { volume harvested. }\end{array}$ & $\begin{array}{l}\text { No incentives in place for } \\
\text { forest management. Some } \\
\text { credits in place that can be } \\
\text { used either in harvesting or } \\
\text { plantation operations. }\end{array}$ \\
\hline $\begin{array}{l}\text { Provision of } \\
\text { forest extension } \\
\text { services }\end{array}$ & $\begin{array}{l}\text { Support for elaboration of } \\
\text { harvesting permits by } \\
\text { municipal governments. No } \\
\text { other support is provided. }\end{array}$ & $\begin{array}{l}\text { State support is provided } \\
\text { based on public forestry } \\
\text { technicians that assist in } \\
\text { preparing forestry permits } \\
\text { for smallholders. }\end{array}$ & $\begin{array}{c}\text { Forestry extension services are } \\
\text { limited by available resources. } \\
\text { Companies provide private } \\
\text { extension services. }\end{array}$ \\
\hline \multicolumn{4}{|c|}{ Better control of timber value chains } \\
\hline $\begin{array}{l}\text { Legality and } \\
\text { verification } \\
\text { system and } \\
\text { procedures }\end{array}$ & $\begin{array}{c}\text { Certificates of Forestry } \\
\text { Origin (CFOs) issued based } \\
\text { on FMPs. Legality } \\
\text { verification is conducted in } \\
\text { log collection centers outside } \\
\text { of the operation areas }\end{array}$ & $\begin{array}{l}\text { Legal verification relies on the } \\
\text { SAF, an informatics system } \\
\text { based on the registration of } \\
\text { users, species and timber } \\
\text { volumes from simplified } \\
\text { forestry plans. }\end{array}$ & $\begin{array}{l}\text { OSINFOR is responsible for in } \\
\text { situ-verification. Other types } \\
\text { of harvesting are regulated by } \\
\text { police, government } \\
\text { prosecutors and regional } \\
\text { forestry authorities. }\end{array}$ \\
\hline
\end{tabular}

Notes: ${ }^{\text {a }}$ from Forest Law No. 1700, 1996; ${ }^{\mathrm{b}}$ Mejía and Pacheco [5]; ${ }^{\mathrm{c}}$ Ministerio del Ambiente [21].

The legal frameworks in the three countries specified forest rights associated with individual, community and public lands, as a keystone to support SFM. Logging permits could only be granted to smallholders and communities who held formal tenure rights and forest concessionaries. In Bolivia and Peru, public forestlands could be given out as concessions to utilize timber and NTFPs [57]. Steps were taken to secure tenure rights for indigenous and non-indigenous communities and smallholders but with significant differences between the two countries. Secure tenure rights to forestlands were expected to reduce conflicts between smallholders and timber enterprises as well as foster investments in SFM [58]. Bolivia demarcated and titled indigenous territories and community lands, followed by the titling of individual landholdings [59]. Peru granted tenure rights to smallholders and indigenous communities but also aggressively fostered agricultural, mining and oil investments, which led to further social conflict [60]. Ecuador regularized land ownership in forestlands but progress was slow in both indigenous and non-indigenous lands and some conflicts persisted [61].

The three countries also adopted regulations to promote SFM, with the main instruments the forest management plan (FMP) and the annual operational plans (AOP). FMPs and AOPs were required for logging in individual landholdings, community lands and forest concessions. Forest regulations were simplified in Ecuador and smallholders only needed to undertake simple management plans but other requirements for permit approval still applied, such as the payment of stumpage fees and the use of accredited foresters to develop the FMPs [5]. Bolivia adopted differentiated management instruments for concessions and small-scale forest management operations and a progressive system of forest taxes. The elaboration of FMPs and AOPs is required for all forest operators [62]. Peru's new regulations for 
timber harvesting were similar to those approved in Bolivia. None of the three countries introduced strong economic incentives, apart from differentiated forest fees, nor an extension of services to support sustainable forest management among the smallholders.

All three countries did improve forest monitoring to assess compliance with forest regulations through the verification of origin of timber supply. Ecuador developed the Forestry Administration Service (Servicio de Administración Forestal, SAF), which includes electronic verification of permits on an online platform. In Bolivia, the Forestry Superintendence and later the Forests and Lands Authority (Autoridad de Fiscalización y Control Social de Bosques y Tierra, ABT), were in charge of legality verification [30]. Legality verification is weaker in Peru, in part because of tensions between the central and regional governments on responsibilities for forest administration. Forest control is now under the Supervisory Body for Forest and Wildlife Resources (Organismo de Supervisión de los Recursos Forestales y de Fauna Silvestre, OSINFOR), created as an independent body from the forest authority [63]. The three countries have similar designs of legality verification: issuance of transport permits based on FMPs, which can be prepared either electronically or manually. Permits are verified at fixed or mobile control points.

The auditing procedures varied in the three countries. In Ecuador, auditors from the Ministry of Environment controlled compliance of FMPs in the plots where forestry operations were carried out. In Peru, the forestry authority asserted little control in the field and more control was exercised over timber transportation. Nowadays, OSINFOR intensively monitors forest concessions and illegal timber operations on public lands. In Bolivia, compliance became monitored at the timber collection points in the forest management units before the logs were transported to sawmills. Chainsaw harvesting was until recently, prohibited in the Bolivian and Peruvian forest laws but it was allowed in Ecuador [64].

The forest reforms neglected to provide incentives and extension services to support sustainable forest management by smallholders. Almost no public extension services for smallholder forestry were implemented, with the exception of Ecuador, where a system of forestry advisors was put in place. It was assumed that smallholders should get access to inputs, extension services and technology from profit providers [65]. Rather than smallholders acquiring services from markets, development projects and NGOs stepped in to provide them but mainly as pilot initiatives with limited opportunity for scaling-up [40].

\subsection{Second Wave of Changes in the Forest Policy Frameworks}

The 2000s again saw policy changes in western Amazon countries. In Bolivia and Ecuador, leftist governments reinvigorated the role of the central state in guiding economic development. This however, undid progress in the devolution of forest responsibilities to municipalities and instead concentrated decision making at intermediate, administrative levels such as provinces, departments or regions. Peru's government did not challenge the central assumptions of market liberalization [66], while Bolivia and Ecuador favored social redistribution of income. All three countries continued to rely on the exploitation of natural resources, notably oil, natural gas and mining $[67,68]$, policies that favored neo-extractive economies, which are considered to provide little long-term economic development [69].

The democratization of society that accompanied state modernization contributed to the strengthening of civil society groups and social organizations from a subnational to a national level. This also increased the input of policy decision-making at the local and national levels, although this varied depending on the country and the specific contexts [70]. The social perspectives favoring smallholder forestry gained importance over time and this also prompted changes in forest regulations. Interestingly, the changes in the forest regulations since the early 2010s have not questioned the centrality of SFM [71].

The second wave of forest policy reforms aimed to facilitate smallholders to undertake SFM but under more flexible forest management options. They also improved incentives to support smallholder forestry, adopted compensations for forest conservation and introduced new methods of timber legality 
verification. These changes were in part, a response to indigenous and non-indigenous peoples and NGOs linked to these groups, who questioned the outcomes obtained during the first wave of forest reforms. Nonetheless, despite opportunities for these groups to influence policy decisions, debates on forest regulations did not adequately accommodate concerns among local participants with the SFM principles.

Some of the second wave of reforms influenced smallholder forestry in western Amazon as follows. In Bolivia, the forest agency simplified regulations to grant communities forest permits [72]. In Peru, a new forestry law in 2011 put in place mechanisms to allow smallholders to conduct legal harvesting operations but in 2016, these mechanisms have not yet being implemented [73]. In Ecuador, a new environmental code which is under discussion, includes revisions with regards to incentives for smallholders to protect their forests, regenerate degraded forests and support agroforestry [74]. Table 3 summarizes the main changes proposed and adopted in the three countries.

In Bolivia, renewed attempts aim at improving the control of illegal timber milling for instance, by implementing new field checkpoints, new ABT offices in areas of significant timber extraction and audits of forest concessions. Community members can obtain Timber Extraction Permits for Small Volumes (Autorización de Aprovechamiento de Volúmenes Menores AAVM), which do not require another plan. Since 2014, community members are allowed to extract $7.07 \mathrm{~m}^{3}$ of timber, six times per year from communal forest lands. A new policy initiative are the Plans for Integrated Forest and Land Management (Plan General de Desarrollo Integral de Bosques y Tierras, PGIBT), which aims to provide a legal basis for both timber and NTFPs use, according to local practices. The Bolivian government has also created the Joint Mechanism of Mitigation and Adaptation for Integrated and Sustainable Management of Forests and Mother Earth to channel public resources to communities in order to support the implementation of PGIBTs [75]. This initiative however, is still in its infancy.

Table 3. Main New Forest Regulations in Bolivia, Ecuador and Peru.

\begin{tabular}{|c|c|c|c|}
\hline Regulations & Bolivia & Ecuador & Peru \\
\hline $\begin{array}{l}\text { Facilitating more } \\
\text { flexible forest } \\
\text { management } \\
\text { systems }\end{array}$ & $\begin{array}{l}\text { Approved new norms in the } \\
\text { period 2012-2014, including: } \\
\text { (i) Timber Extraction Permit } \\
\text { for Small Volumes; (ii) Plan } \\
\text { for Integrated Forest and } \\
\text { Land Management; } \\
\text { and (iii) mechanisms improving } \\
\text { the inspections of concessions. }\end{array}$ & $\begin{array}{l}\text { Recognized the importance of } \\
\text { maintaining simplified forest } \\
\text { management plans. Proposed the } \\
\text { need to mandate for the elaboration of } \\
\text { integrated management plans at the } \\
\text { property level applying since } 2014 \text {. }\end{array}$ & $\begin{array}{l}\text { Provisions issued in } 2015 \\
\text { proposed the establishment of } \\
\text { 'local forests' as equivalent to } \\
\text { social concessions but no } \\
\text { provisions exists to formalize } \\
\text { small-scale timber } \\
\text { extraction operations. }\end{array}$ \\
\hline $\begin{array}{l}\text { Improving } \\
\text { incentives to } \\
\text { support } \\
\text { smallholder } \\
\text { forestry }\end{array}$ & $\begin{array}{l}\text { Introduced public funding for } \\
\text { productive projects to support } \\
\text { sustainable forest management } \\
\text { under the Joint Mechanism of } \\
\text { Mitigation and Adaptation for } \\
\text { Integrated and Sustainable } \\
\text { Management of Forests and } \\
\text { Mother Earth since 2012. }\end{array}$ & $\begin{array}{l}\text { A program to facilitate technical } \\
\text { support to smallholders } \\
\text { (Socio-Manejo) since } 2011 \text { but not } \\
\text { provision of financial incentives. } \\
\text { Introduced in new Environmental } \\
\text { Code (drafted in 2014) incentives to } \\
\text { agroforestry systems. }\end{array}$ & $\begin{array}{l}\text { Introduced since } 2011 \text { a national } \\
\text { compensation program that } \\
\text { provides resources to } \\
\text { smallholders in order to } \\
\text { improve their production } \\
\text { practices and competitiveness, } \\
\text { including forest use. }\end{array}$ \\
\hline $\begin{array}{l}\text { Payments and } \\
\text { compensations } \\
\text { for forests } \\
\text { conservation }\end{array}$ & $\begin{array}{l}\text { No payments are in place; but an } \\
\text { institutional mechanisms is under } \\
\text { development to provide rewards } \\
\text { to good local forest stewards, } \\
\text { mainly in community lands. }\end{array}$ & $\begin{array}{l}\text { Payments for conservation are } \\
\text { based on area protected } \\
\text { (4-40 USD/year/hectare) based on } \\
\text { predefined selection criteria of } \\
\text { protected hectares. }\end{array}$ & $\begin{array}{l}\text { Payments for conservation are } \\
\text { based on area protected } \\
\text { (3.34 USD/year/hectare) but } \\
\text { cover only a small number } \\
\text { of communities. }\end{array}$ \\
\hline $\begin{array}{c}\text { Adjusting } \\
\text { procedures to } \\
\text { enhance timber } \\
\text { legality verification }\end{array}$ & $\begin{array}{l}\text { Implemented an electronic system } \\
\text { for issuance of timber origin } \\
\text { certificates in 2011. Improved } \\
\text { control in processing centers since } \\
\text { 2012. No mechanisms for legality } \\
\text { verification of timber extraction in } \\
\text { small volumes. }\end{array}$ & $\begin{array}{l}\text { Introduced a registry of timber } \\
\text { processors, additional control in } \\
\text { consumption center depots and } \\
\text { improved systems to link timber } \\
\text { supply to demand applies since } 2010 \text {. }\end{array}$ & $\begin{array}{l}\text { Improved information systems, } \\
\text { and control of forests permits } \\
\text { since 2012. Made local } \\
\text { governments co-responsible for } \\
\text { the functioning and } \\
\text { maintenance of timber legality } \\
\text { verification systems. }\end{array}$ \\
\hline
\end{tabular}

In Ecuador, since the National Plan of Well-being was issued in 2007, the government has assumed a leading role in the control and management of natural and planted forests [76,77]. The introduction in the early 1990s of simplified harvesting plans was an important step in promoting smallholder 
forestry [34]. Recently, a new program offers technical assistance to smallholders to obtain forestry permits and some economic incentives support forest conservation. A new draft Environmental Law introduces the Integrated Management Plan to be implemented at farm level, which also requires smallholders to register their properties in the Forestry Registry. Forest conversion will require special permission from the Ministry of Environment but smallholders and indigenous communities may implement local practices as long as they are not against the existing law. These provisions however, only apply to timber for domestic household needs and do not apply to commercial logging [74].

Peru's regulations for forest management remain complex following the new 2011 Forestry Law. The 2000 Forestry Law favored forest management in concessions [78] but neglected the smallholders. The new 2011 Law No. 29763 introduces Management Plans for Modalities of Reduced Scale Extraction, to apply to communities, individual landholdings and local social concessions (bosques locales). However, civil society groups have complained about the lack of credit and technical support for the proper functioning of these plans [79], even though the law states that support will be provided [80]. Members of indigenous and non-indigenous communities favor formalizing their access to forests through individual permits. Although the law allows small-scale operations to be undertaken with simplified management plans, the procedure is not yet well established. Community organization representatives have endorsed the regulations but with the condition that rural communities will gain tenure rights over the lands over which they claim rights [81].

\section{Implications of Forest Reforms for Smallholder Forestry}

The institutional and regulatory changes to implement SFM in western Amazonia focused on clarifying forest tenure rights, instruments to regulating forest use and legal timber verification. The forest reforms however, failed to address critical constraints that smallholders face when trying to adopt SFM and engage in timber markets. Recognition of tenure rights is difficult to implement, smallholder's legalization of timber extraction is costly and the economic rationale of small-scale timber extraction often prevents adoption of SFM. Below, we discuss these issues in more detail.

\subsection{Recognition of Tenure Rights to Support Smallholder Forestry}

Policy reforms in the three countries included regulations to grant tenure rights to smallholders and indigenous people but their outcomes differed, due to existing land claims and how the process of land regularization was implemented in practice. In Bolivia, indigenous people received tenure rights over indigenous territories, including exclusive rights to use forest resources. Tenure rights were also given to non-indigenous communities and to individual landholders. In Ecuador, individual access rights to forests were recognized for individual landholders and collective tenure rights were recognized for indigenous communities. In Peru, individual and collective rights to use forest resources were also recognized. In the three countries, community and individual landholders are required to detail a FMP that needs to be approved in order to harvest timber for commercial purposes.

The recognition of indigenous rights over forestlands moved fast in Bolivia [82] and Ecuador [83,84], but it faced some institutional constraints in Peru [85]. The titling of territories held by non-indigenous communities and individual landholders proved cumbersome in all three countries because governments were unwilling to cover related costs. Individual landholders have been able to acquire land as part of government programs, granting rights in colonized lands; they simply encroached public lands or they acquired land in informal land markets $[84,86]$. In some cases, land regularizations indirectly stimulated occupation of public lands, as individual landholders expected that state agencies would formalize tenure rights once public lands were occupied and land improvements could be demonstrated [30].

While secure tenure rights are an important condition for smallholders to adopt SFM, having tenure does not automatically lead to adhering to SFM principles [87]. In areas more distant from regional markets, with deficient infrastructure but abundant timber, land tenure is often greatly disputed, while timber extraction is poorly monitored. In those areas, local forest users depend more 
on timber extraction for their livelihoods than when they live closer to regional towns. But they also rely more on intermediaries and companies that buy timber or facilitate logging and the latter captures a higher portion of the benefits [31]. In locations better connected to markets, tenure rights are clearer and more effectively enforced. In these conditions, smallholders depend less on timber income and have less incentives to undertake SFM. Closer to markets, high-value timber species are no longer available. As mentioned before, timber markets are now often turning to fast-growing tree species from smallholder plots, which increases forestry options for smallholders [36,37].

\subsection{Barriers to Adoption of Sustainable Forest Management}

The regulations to promote SFM introduced institutional barriers and bureaucratic procedures that increased the transaction costs for smallholders in undertaking legal timber extraction $[9,88,89]$, which reduced the benefits for smallholders [90]. The recommended SFM models require input and technologies that are not easily adopted by smallholders who mostly rely on chainsaw milling [91]. Local collaboration is obligatory for smallholders if they use FMP to undertake SFM [92]. Some indigenous groups established community enterprises [93]. Only communities that received external assistance with formulating FMPs; and accessing capital and technologies made significant progress in adopting SFM practices $[33,39,94]$. Where this happened however, smallholders became more vulnerable to price fluctuations in the timber markets [95-97]. In addition, social differentiation tends to increase with greater access to timber markets [64].

As argued above, improved tenure rights are not enough for smallholders to fully capture the economic benefits from their forests. Smallholders have to follow cumbersome regulations when logging their timber for commercial purposes and often the benefit obtained from harvesting does not justify the payment of the permit costs $[60,98]$. Also, the market tends to absorb only some species, which stimulates selective logging of the most valuable species. Estimates of costs and benefits from the different harvesting procedures can be found elsewhere, see [4-6]. The costs involved in obtaining permits and the often low benefits derived from harvesting lead smallholders to conducting their operations outside of the law. In addition, forest technicians have little interest in formulating FMPs in small areas because that yields smaller income than from the larger areas [10].

The main criticisms of the first wave of forest reforms in the three countries is that they imposed forest management that demanded external inputs and finance [33]. Regulations were imposed but they did not come with extension, financial support, or incentives to gradual adopt SFM. Central government agencies and not decentralized agencies continued with forest administration [99]. Resources transferred to lower tiers of government (municipalities in Ecuador and Bolivia and regional governments in Peru) for forest control, or supporting local forest users were minimal; and local governments could not generate significant rents from the exploitation of forests within their jurisdiction in order to pay for any support [100].

Failing to provide financial incentives to support the adoption of SFM by smallholders has likely been the most important omission in the policy design, even more so since command-and-control approaches increased the costs to local forest users and required law enforcement coordination among the state agencies. Where forestry-oriented projects and NGOs provided technical assistance and financial resources to community forestry initiatives [40], they also subsidized the certification of community forest management operations, if and when it happened. Yet, even in most cases of community forestry certification, the local forest user groups were unable to continue forest certification as the high costs were not compensated with incomes from sales, mostly in domestic markets [101].

To obtain financial support for forest operations, entrepreneurs often turn to informal money lenders, as shown by studies in Bolivia [4], Ecuador [5] and Peru [6] and this reinforces existing market asymmetries. When smallholders aim to undertake legal forest exploitation their FMPs, or equivalent instruments, need to be approved by foresters accredited by the respective national professional bodies. In Ecuador the government has put in place a facility to support smallholders, but it has insufficient capacity to meet demand [5] and no similar facilities exists in Bolivia and Peru. 


\subsection{Control of Legal Timber Supply and Persistence of Informal Practices}

The control of timber legality is costly and often quite ineffective. This is partly a result of a chronic lack of resources for law enforcement but also because of persistent, corrupt practices of public agencies in charge of environmental administration and environmental law enforcement. Local participants also persistently find ways to circumvent the law, a phenomenon common in tropical countries where timber contributes to income for local populations [53,98,102]. Almost all participants in the timber value chain in western Amazon comply to some degree with the law but also engage in some illegal practices [4-6]. Thus, legal and illegal logging activities are intertwined realities that cannot easily be separated. Market opportunities and risks calculations, in addition to lacking enforcement and corruption, are important reasons why forest entrepreneurs, large or small, turn to illegal practices. It is unlikely that illegality will be eliminated only using the prevailing command-and-control approach [103].

Some authors suggest that the economic rationale of small-scale timber extraction is different from large-scale operations [104] and that market imperfections affect smallholders more than larger operators [88]. Many smallholders prefer to use chainsaws to undertake logging and sawing timber using their own labor, rather than pay for somebody else's [105]. However, even then they require relatively costly advances of capital from intermediaries. The alternative options for many is to sell standing trees to intermediaries or chainsaw millers [106]. Intermediaries usually have the resources and contacts to obtain the necessary permits, or know how to legalize timber [34]. Smallholders usually have little choice but to accept the conditions imposed by these intermediaries [107].

As a result, smallholders engage in vigorous timber networks, where intermediaries play a central role but in which buyers who reside in cities, have a major influence on prices [108,109]. Specialized chainsaw operators as well as intermediaries who have their own harvesting teams, organize the logging activities. They have the resources to obtain permits-via legal or illegal means-and to undertake logging operations [5]. Some argue that these participants should be eliminated from the timber supply chain [110]. They do however, play an important role in the timber markets as they supply the capital and facilitate trade along the network, which are essential for the supply chain to work [88].

Timber produced in the Amazon region in the three countries is sold in local markets, mostly in the region's towns and cities and distant markets in the larger cities (e.g., La Paz and Santa Cruz in Bolivia; Lima and Piura in Peru; and Quito and Cuenca in Ecuador). Amazon timber is used for construction and furniture manufacturing and also sold to external markets in the Argentina, Chile, USA and lately to China [111]. The cities in the Amazon are the first link to end-markets through an extended intermediation network [99]. For instance in Pucallpa, Peru, a network of Chinese families purchases timber from small- to large-scale extractors and export to Chinese markets [112]. Anecdotal evidence suggests that timber brokers linked to domestic markets operate in the same way. Studies suggest that timber extracted through illegal ways can be legalized by different means along the supply chain and costs tend to vary depending on volumes, species and risk considerations [113,114]. Most participants who make a profit from illegal timber strongly resist change to current practices [115].

\section{Discussion and Conclusions}

This paper provides a comparative perspective on the implementation and outcomes of forest policy reforms in Bolivia, Ecuador and Peru and how these affect smallholder forestry in their respective Amazon regions. The reforms, implemented since the mid-1990s created new national forestry regimes that have changed little until today. The reforms were guided by the SFM principles and sought to foster forest management that ensured long term forest productivity. The reforms clarified forest rights, supported improved forest management and possessed legal timber verification. The forest reforms aligned with wider market liberalization and state democratization. The main assumption of these forest reforms were that forest management by smallholders could contribute in generating 
incomes from the supply of timber to the markets, while addressing the need for local participation and livelihoods.

We compared policy reforms and implementation in these countries responding to the questions: What is the influence of tenure rights in stimulating smallholder forestry? What are the main barriers preventing the adoption of SFM by smallholders? And why does unauthorized timber extraction persist among smallholders? Answering these questions is central to further advance forest policy in Western Amazon while delivering positive outcomes for smallholder livelihoods and forest protection. These three countries adopted a similar policy framework in order to comply with the policy goals aligned to SFM and have contributed to the common lessons learnt. Nonetheless, these same countries have over time adopted diverging pathways in order to overcome some of the main failures of the forest reforms, which are related to both their design and implementation.

The forest reforms were implemented in a context of increasing local demands for tenure and claims for growing local participation. Governments to different degrees, made efforts to attend these local demands since formal tenure became a condition for local people to acquire forest rights. Nonetheless, several administrative and political constraints limited a majority of smallholders and communities who were able to formalize their access to land, thus preventing them to access timber in legal ways. In addition, local participants with formal tenure rights were not able to fully benefit from their forest resources, even when trying to adhere to SFM. Many barriers worked against this, including: legal, which implied additional transactions costs; market conditions including, for example, asymmetries in bargaining power and dependence on intermediaries; and difficulties for accessing technical services. In addition, timber markets demanded only a few species, which reduced the incentives to adhere to SFM.

Despite government efforts to improve the control of timber harvesting, smallholders and other local participants have found ways to circumvent the institutional barriers and reduce the transaction costs imposed by timber legality verification. Smallholders have built multiple strategies to integrate into networks supplying timber to the main cities and export markets. But many issues related to efficiencies in economic rents, the capture and distribution of benefits persist. The lack of compliance with forest regulations often leads to important state losses due to tax evasion. Informal timber markets are characterized by significant asymmetries that often result in unequal capturing of benefits. Usually, informal markets favor intermediaries who have access to capital to meet the timber requests from buyers in the cities, or international markets. The incomes captured by smallholders from timber are not high and often complement income from agriculture and off-farm activities. While smallholders harvest relatively low timber volumes compared to large operations, their economic reality and the limited support they receive, limits their pursuit of planning and the organization of timber extraction in a way that optimizes the available forest resources, as should be the case when a FMP is implemented.

Once the forest reforms were in place, regulators and administrators favored command-andcontrol rather than using incentive instruments (e.g., extension and financial services) to facilitate SFM. This was an important omission in the policy design, even more so since command-and-control approaches are relatively costly and require coordination between the law enforcement state agencies. Some forest projects and NGOs provided support to smallholders but they were unable to meet the overall need for extension and financial services. Finance is often facilitated by intermediaries but this reinforces existing asymmetries in the supply chain. In addition, the command-and-control approach emphasized forest conservation to the detriment of people's livelihoods, which paradoxically undermined the capacities of smallholders to undertake SFM.

The lack of incentives for smallholders has become a critical issue and governments have gradually made changes in the policy frameworks, particularly since the late 2000s. The approaches in overcoming existing constraints have however, been different. In Bolivia and Ecuador, governments are attempting to implement policy instruments that could better address the needs of smallholders. The main goal of the new regulations, already issued or under discussion, is to ease administrative 
processes such as obtaining extraction permits, which should vastly improve legal timber extraction and also enhance smallholder bargaining power in local timber markets, or with timber traders. In addition, there is a move favoring a more integrated perspective for undertaking forest and farm management, providing financial support for forest conservation and restoration, adopting more simplified small-scale timber regulations and improving online systems for timber legality verification. Interestingly, in Peru more conventional views on command-and-control approaches for the control of illegal logging still prevail.

The forest reforms undertaken in the western Amazon constitute a case in which changes in the broader policy regime, linked to market liberalization and state democratization, marked the beginning of new forest policy regimes that introduced SFM, based on the assumption that its adoption by different stakeholders, including smallholders, would be stimulated by markets that required a legal and sustainable timber supply. This assumption did not hold true in practice as smallholders could not afford the costs and the timber markets preferred the cheapest timber, which usually originated from illegal operations. At the same time, the governments retained a command-and-control approach but with no incentives to support a gradual adoption of SFM. The lack of incentives to support smallholders in pursuing SFM, along with little realistic forest regulations and ineffective enforcement, have tended to work against the goal embraced by the forest reforms. Under this institutional context, smallholders found ways to navigate the new legal and institutional landscape but faced constraints that limited their capturing of benefits in the timber markets, which may work against forest conservation in the long run.

Interestingly, changes in the broader policy regimes (with Bolivia and Ecuador moving away from neoliberal policies and Peru continuing to embrace them), have not affected the foundations of the current forest policy regimes, which remains based on SFM principles. This possibly displays the level of acceptance and durability of SFM, which is a constant in the three countries. This is likely the most interesting finding and highlights the value of a comparative perspective for assessing the policy changes and their outcomes. In addition, our comparative analysis suggests that countries are diverging and exploring different pathways to overcome institutional constraints.

One pathway is to insist on conventional approaches, to enforce SMF and increase state control in order to eliminate illegal logging, with outcomes that we have described in this paper. Another pathway is insisting on the need to build more flexible and integrated frameworks of forest management that rely on the capacities of smallholders to manage their forests and create the conditions for them to make meaningful decisions of how to pursue this management. Attempts to build these flexible and integrated frameworks should however, involve participation of all stakeholders (i.e., smallholders, chainsawers, intermediaries, forest enterprises and buyers). Therefore, there is a need for options that can reduce the prevailing market asymmetries, strengthen existing local institutions; and networks that could minimize those imbalances through the improvement of the conditions for all participants to be able to bargain within the markets. State government and agencies at the different levels should play a facilitating, rather than a controlling role, for durable solutions to emerge.

Acknowledgments: The authors would like to thank the large number of key informants that contributed with insights and perspectives about forest policy processes and implementation in Bolivia, Ecuador and Peru. We would also like to thank the various state agencies in these countries that shared information and studies with us that we used in this paper. Pablo Pacheco acknowledges funding received for this research from the CGIAR Research Program on Forests, Trees and Agroforestry (CRP-FTA). This collaborative program aims to enhance the management and use of forests, agroforestry and tree genetic resources across the landscape from forests to farms. The Center for International Forestry Research (CIFOR) leads CRP-FTA, in partnership with Bioversity International, Centro Agronómico Tropical de Investigación y Enseñanza (CATIE), Agricultural Research for Development (CIRAD), the International Center for Tropical Agriculture (CIAT), and the World Agroforestry Centre (ICRAF). De Jong's work contributing to this paper was supported the Japan Society for the Promotion of Science (Grant No. 24310182, 5008).

Author Contributions: Pablo Pacheco designed the research for this paper and coordinated the writing process. $\mathrm{He}$ is the main author of the different sections. Elena Mejía contributed with information and analysis on the Ecuadorian and Peruvian cases. Walter Cano contributed with information and analysis on the Bolivian case, Wil de Jong contributed to writing the paper. 
Conflicts of Interest: The authors declare no conflict of interest.

\section{References}

1. Pokorny, B.; Pacheco, P. Money from and for forests: A critical reflection on the feasibility of market approaches for the conservation of Amazonian forests. J. Rural Stud. 2014, 36, 441-452. [CrossRef]

2. Smith, J.; Colan, V.; Sabogal, C.; Snook, L. Why policy reforms fail to improve logging practices: The role of governance and norms in Peru. For. Policy Econ. 2006, 8, 458-469. [CrossRef]

3. Stevens, C.; Winterbottom, R.; Springer, J.; Reytar, K. Securing Rights, Combating Climate Change: How Strenghtening Community Forest Rights Mitigates Climate Change; WRI, RRI: Washington, DC, USA, 2014.

4. Cano, W.; van de Rijt, A.; de Jong, W.; Pacheco, P. Aprovechamiento y Mercados de la Madera en el Norte Amazónico de Bolivia; CIFOR: Bogor, Indonesia, 2015.

5. Mejía, E.; Pacheco, P. Aprovechamiento Forestal y Mercados de la Madera en la Amazonía Ecuatoriana; Center for International Forestry Research (CIFOR): Bogor, Indonesia, 2013.

6. Mejía, E.; Cano, W.; de Jong, W.; Pacheco, P.; Tapia, S.; Morocho, J. Actores, Aprovechamiento de Madera y Mercados en la Amazonía Peruana; CIFOR: Bogor, Indonesia, 2015.

7. ITTO. Country Profiles: Latin America and the Caribbean; ITTO: Yokohama, Japan, 2011.

8. WWF Ecoregions Profile. Available online: http://www.worldwildlife.org/science/ecoregions/ (accessed on 26 August 2016).

9. Kaimowitz, D. Forest law enforcement and rural livelihoods. Int. For. Rev. 2003, 5, 199-210. [CrossRef]

10. CORPEI. Planeación Estratégica: Sub-Sector Plantaciones Forestales; Corporación de Promoción de Exportaciones e Inversiones (CORPEI): Quito, Ecuador, 2007.

11. Amazonas del Ecuador: Oro Negro o Verde? Available online: http://blog.globalforestwatch.org/2015/07/ amazonas-del-ecuador-oro-negro-o-verde/ (accessed on 26 August 2016).

12. Killeen, T.; Calderon, V.; Soria, L.; Quezada, B.; Steininger, M.K.; Harper, G.; Solórzano, R.; Tucker, C.J. Fifty years of land-use change in Bolivia: Exponential growth and no change in sight. Ambio 2007, 7, 600-606. [CrossRef]

13. Del Ambiente, M. El Perú de los Bosques; Ministerio del Ambiente: Lima, Peru, 2011.

14. ABT. Audiencia Pública de Rendición de Cuentas: Resultados Gestión 2013; Autoridad de Fiscalización Y Control Social de Bosques y Tierras (ABT): Santa Cruz, Bolivia, 2014.

15. Del Ambiente, M. Programa Nacional de Conservación de Bosques; Ministerio del Ambiente: Lima, Peru, 2014.

16. De Agricultura, M. Perú Forestal en Números año 2012; Dirección General Forestal y de Fauna Silvestre-DGFFS: Lima, Peru, 2012.

17. ITTO. Country profile: Peru. In Status of Tropical Forest Management 2011; Blaser, J., Sarre, A., Poore, D., Johnson, S., Eds.; International Tropical Timber Organization (ITTO): Yokohama, Japan, 2011; pp. 363-373.

18. Pacheco, P.; Benatti, J.B. Tenure Security and Land Appropriation under Changing Environmental Governance in Lowland Bolivia and Pará. Forests 2015, 6, 464-491. [CrossRef]

19. Añazco, M.; Morales, M.; Palacios, W.; Vega, E.; Cuesta, A.L. Sector Forestal Ecuatoriano: Propuestas para una Gestión Forestal Sostenible; Ecobona-Intercooperation: Quito, Ecuador, 2010.

20. FAO. Paquete de Informe Sobre los Bosques 2015; FAO, FE, OIMT, OFAC, UNECE, MPWG: Quito, Ecuador, 2015.

21. De Ministros, P.D.C. Supervisión y Fiscalización del OSINFOR en Permisos Forestales Otorgados a Comunidades Nativas; Comunidades nativas, medio ambiente, bosques, políticas: Lima, Peru, 2014.

22. ABT. Informe Anual 2011; Autoridad de Fiscalización y Control Social de Bosques y Tierras (ABT): Santa Cruz, Bolivia, 2012.

23. OSINFOR. Informe de Gestión Anual al 2014; Organismo de Supervisión de los Recursos Forestales y de Fauna Silvestre (OSINFOR): Lima, Peru, 2014.

24. Sierra, R. The role of domestic timber markets in tropical deforestation and forest degradation in Ecuador: Implications for conservation planning and policy. Ecol. Econ. 2001, 36, 327-340. [CrossRef]

25. Galarza, E.; Serna, K.L. Son sostenibles las concesiones en el Perú? Econ. Soc. 2005, 56, 34-41.

26. INTERPOL. OMA Operación Contra el Comercio de Madera Ilegal en el Perú con el Apoyo de Interpol y la OMA. Available online: http:/ /www.interpol.int/es/Centro-de-prensa/Noticias/2014/N2014-139/ (accessed on 26 August 2016).

27. MINCETUR. Estudio de Viabilidad Técnico-Económica para el Uso de Residuos; Unión Europea: Lima, Peru, 2010. 
28. AIDER. Utilización Industrial y Mercado de Diez Especies Maderables; Asociación para la Investigación y Desarrollo Integral (AIDER): Lima, Peru, 2012.

29. SNV/CITE. Estudio del Mercado Nacional de Madera y Productos de Madera para el Sector de la Construcción; SNV (Servicio Holandes de Cooperacion al desarrollo); CITE (Centro de Innovación Tecnológico): Lima, Peru, 2009.

30. Müller, R.; Pacheco, P.; Montero, J.C. The Context of Deforestation and Forest Degradation in Bolivia: Drivers, Agents and Institutions; CIFOR: Bogor, Indonesia, 2014.

31. De Jong, W.; Cano, W.; Zenteno, M.; Soriano, M. The legally allowable versus the informally practicable in Bolivia's domestic timber market. For. Policy Econ. 2014, 48, 46-54. [CrossRef]

32. Cronkleton, P.; Pacheco, P.; Ibargüen, R.; Albornoz, M.A. Reformas en la Tenencia Forestal en Bolivia: La gestión Comunal en las Tierras Bajas; CIFOR and CEDLA: La Paz, Bolivia, 2009; p. 110.

33. Pokorny, B.; Johnson, J. Community Forestry in the Amazon: The Unsolved Challenge of Forests and the Poor; ODI: London, UK, 2008.

34. Mejia, E.; Pacheco, P.; Muzo, A.; Torres, B. Smallholders and Timber Extraction in the Ecuadorian Amazon: Amidst Market Opportunities and Regulatory Constraints. Int. For. Rev. 2015, 17, 38-50. [CrossRef]

35. Pinedo-Vasquez, M.; Zarin, D.J.; Coffey, K.; Padoch, C.; Rabelo, F. Post-Boom Logging in Amazonia. Hum. Ecol. 2001, 29, 219-239. [CrossRef]

36. Erazo, G.; Izurieta, J.; Cronkleton, P.; Larson, A.; Putzel, L. The Use of Pigüe (Piptocoma Discolor) by Smallholders in Napo, Ecuador: Sustainable Management of a Pioneer Timber Species for local Livelihoods; Center for International Forestry Research (CIFOR): Bogor, Indonesia, 2013.

37. Putzel, L.; Cronkleton, P.; Larson, A.M.; Pinedo-Vasquez, M.; Salazar, O.; Sears, R. Producción y Comercialización de Bolaina (Guazuma Crinita), una Especie Amazónica de Rápido Crecimiento: Un Llamado a la Adopción de un Marco de Políticas que Apoye los Medios de Vida; Center for International Forestry Research (CIFOR): Bogor, Indonesia, 2013.

38. Padoch, C.; Brondizio, E.; Costa, S.; Pinedo-Vasquez, M.; Sears, R.R.; Siqueira, A. Urban forest and rural cities: Multi-sited households, consumption patterns, and forest resources in Amazonia. Ecol. Soc. 2008, $13,2$.

39. Zenteno, M. Quantitative Analysis of Livelihoods in Community Forestry in the Northern Bolivian Amazon; PROMAB: Riberalta, Bolivia, 2013; p. 224.

40. Benneker, C. Dealing with the State, the Market and NGOs: The Impact of Institutions on the Constitution and Performance of Community Forest Enterprises (CFE) in the Lowlands of Bolivia; Wageningen University: Wageningen, The Netherlands, 2008.

41. Porro, R.; Lopez-Feldman, A.; Vela-Alvarado, J.W.; Quiñonez-Ruíz, L. Forest use and agriculture in Ucayali, Peruvian Amazon: Interactions among livelihood strategies, income and environmental outcomes. Tropics 2014, 23, 47-62. [CrossRef]

42. Zenteno, M.; de Jong, W.; Boot, R.; Zuidema, P.A. Learning from the past: Trends and dynamics in livelihoods of Bolivian forest communities. Environ. Sci. Policy 2014, 40, 36-48. [CrossRef]

43. Sunderlin, W.; Angelsen, A.; Belcher, B.; Burgers, P.; Nasi, R.; Santoso, L.; Wunder, S. Livelihoods, forests, and conservation in developing countries: An overview. World Dev. 2005, 33, 1383-1402. [CrossRef]

44. Nygren, A. The role of commercial forestry in rural livelihoods. In Conferencia Internacional de PyMEs Forestales; Centro Agronómico Tropical de Investigación y Enseñanza: Turrialba, Costa Rica, 2006.

45. Pretzsch, J. Forest related rural livelihoods strategies in national and global development. For. Trees Livelihoods 2005, 15, 115-127. [CrossRef]

46. Ocampo, J.A.; Stiglitz, J.E. Capital Market Liberalization and Development; Oxford University Press: New York, NY, USA, 2008.

47. Kaimowitz, D.; Thiele, G.; Pacheco, P. The effects of structural adjustment on deforestation and forest degradation in lowland Bolivia. World Dev. 1999, 27, 505-520. [CrossRef]

48. Zimmerer, K.S. “Conservation Booms” with agricultural growth? Sustainability and Shifting Environmental Governance in Latin America, 1985-2008 (Mexico, Costa Rica, Brazil, Peru, Bolivia). Lat. Am. Res. Rev. 2011, 46, 82-114. [CrossRef]

49. Kaimowitz, D.; Vallejos, C.; Pacheco, P.B.; Lopez, R. Municipal governments and forest management in lowland Bolivia. J. Environ. Dev. 1998, 7, 45-59. [CrossRef] 
50. Willis, E.G.; Christopher, C.B.; Haggard, S. The Politics of Decentralization in Latin America. Latin Am. Res. Rev. 1999, 34, 7-50.

51. Pearce, D.; Putz, F.E.; Vanclay, J.K. Sustainable forestry in the tropics: Panacea or folly? For. Ecol. Manag. 2003, 172, 229-247. [CrossRef]

52. Putz, F.E.; Sist, P.; Fredericksen, T.; Dykstra, D. Reduced-impact logging: Challenges and opportunities. For. Ecol. Manag. 2008, 256, 1427-1433. [CrossRef]

53. Brown, D.; Schreckenberg, K.; Bird, N.; Cerutti, P.; del Gatto, F.; Diaw, C.; Fomété, T.; Luttrell, C.; Navarro, G.; Oberndorf, R.; et al. Legal Timber Verification and Governance in the Forest Sector; Overseas Development Institute: London, UK, 2008; p. 232.

54. Quevedo, L. Forest certification in Bolivia. In Proceedings of the Certification Symposium, New Haven, CT, USA, 10-11 June 2004; Yale School of Forestry and Environmental Studies: New Haven, CT, USA, 2004.

55. Pacheco, P.; Barry, D.; Cronkleton, P.; Larson, A. The Recognition of Forest Rights in Latin America: Progress and Shortcomings of Forest Tenure Reforms. Soc. Nat. Resour. 2011, 25, 556-571. [CrossRef]

56. Pacheco, P. Revisiting 10 years of the new forestry regime's implementation in Bolivia. Recur. Nat. Ambient. 2006, 49-50, 58-67.

57. Barrantes, R.; Burneo, D.; Chávez, J.C.; Falconí, F.; Galarza, E. La Política Forestal en la Amazonía Andina; Consorcio de Investigación Económica y Social: Lima, Perú, 2005; p. 600.

58. Larson, A.M.; Barry, D.; Dahal, G.R.; Colfer, C.J.P. Forests for People: Community Rights and Forest Tenure Reform; Earthscan: London, UK, 2010; p. 263.

59. INRA. Resultados de la Revolución Agraria 1996-2012; Instituto Nacional de Reforma Agraria: La Paz, Bolivia, 2012.

60. OXFAM. Geographies of Conflict: Mapping Overlaps between Extractive Industries and Agricultural Land Uses in Ghana and Peru; OXFAM: Washington, DC, USA, 2014.

61. Holland, M.B.; de Koning, F.; Morales, M.; Naughton-Treves, L.; Robinson, B.E.; Suárez, L. Complex tenure and deforestation: Implications for conservation incentives in the Ecuadorian Amazon. World Dev. 2014, 55, 21-36. [CrossRef]

62. Pacheco, P. Enfoques Forestales Homogéneos para Actores Diversos: La Encrucijada del Manejo de Bosques en Bolivia. Documento de Trabajo; Programa de Naciones Unidas para el Desarrollo (PNUD): La Paz, Bolivia, 2007.

63. Defensoría del Pueblo. La Política Forestal y la Amazonía Peruana: Avances y Obstáculos en el Camino Hacia la Sostenibilidad; Defensoría del Pueblo: Lima, Perú, 2012.

64. Cano, W.; de Jong, W.; Zuidema, P.A.; Boot, R. Diverse local regulatory responses to a new forestry regime in forest communities in the Bolivian Amazon. Land Use Policy 2014, 39, $224-232$.

65. Farrington, J. Public Sector Agricultural Extension: Is There Life after Structural Adjustment?; ODI, Natural Resource Perspectives: London, UK, 1994.

66. Lust, J. Social Struggle and the Political Economy of Natural Resource Extraction in Peru. Crit. Sociol. 2016, 42, 195-210. [CrossRef]

67. Bebbington, A.; Bebbington, D.H. An Andean Avatar: Post-Neoliberal and Neoliberal Strategies for Securing the Unobtainable. New Polit. Econ. 2011, 16, 131-145. [CrossRef]

68. Zimmerer, K.S. Environmental governance through "Speaking Like an Indigenous State" and respatializing resources: Ethical livelihood concepts in Bolivia as versatility or verisimilitude? Geoforum 2015, 64, 314-324. [CrossRef]

69. Flemmer, R.; Vacaflor, A.S. Unfulfilled promises of the consultation approach: The limits to effective indigenous participation in Bolivia's and Peru's extractive industries. Third World Q. 2016, 37, 172-188. [CrossRef]

70. The New Andean Politics: Bolivia. Peru, Ecuador. Available online: https://www.opendemocracy.net/johncrabtree/new-andean-politics-bolivia-peru-ecuador (accessed on 26 August 2016).

71. Pacheco, P.; de Jong, W.; Johnson, J. The evolution of the timber sector in lowland Bolivia: Examining the influence of three disparate policy approaches. For. Policy Econ. 2010, 12, 271-276. [CrossRef]

72. Muller, R.; Pistorius, T.; Rohde, S.; Gerold, G.; Pacheco, P. Policy options to reduce deforestation based on a systematic analysis of drivers and agents in lowland Bolivia. Land Use Policy 2013, 30, 895-907. [CrossRef]

73. Cossío-Solano, R.E.; Guariguata, M.R.; Menton, M.; Capella, J.L.; Rios, L.; Peña, P. El Aprovechamiento de Madera en las Concesiones Castañeras (Bertholletia Excelsa) en Madre de Dios, Perú: Un Análisis de su Situación Normativa; CIFOR: Bogor, Indonesia, 2011. 
74. Ecuador, A.N.D. Proyecto de Código Orgánico del Ambiente; Asamblea Nacional del Ecuador: Quito, Ecuador, 2014.

75. Pacheco, D. Hacia la Descolonización de las Políticas Ambientales y de los Bosques: El Mecanismo Conjunto de Mitigación y Adaptación para el Manejo Integral y Sustentable de los Bosques y la Madre Tierra; Fundación de la Cordillera, Universidad de la Cordillera: La Paz, Bolivia, 2014.

76. Navarro, G.; Gatto, F.D.; Schroeder, M. Sistema Ecuatoriano Tercerizado de Control Forestal; CATIE: Turrialba, Costa Rica, 2009.

77. Ministerio del Ambiente. Plan Nacional de Restauración Forestal; MAE: Quito, Ecuador, 2014.

78. García, T. Estado de la Gobernanza Forestal Referente a la Madera Ilegal; Lima, Peru, 2014.

79. Hajek, F. Opciones de Inversión Privada e Instrumentos Financieros para el Sector Forestal del Perú; Nature Service Peru: LIma, Peru, 2012.

80. Ministerio de Agricultura. Ley Forestal No. 29763; Lima, Peru, 2011.

81. SPDA. Organizaciones Indígenas Llegan a Acuerdo Sobre Reglamento de Nueva Ley Forestal y de Fauna Silvestre; Sociedad Peruana de Derecho Ambiental: Lima, Peru, 2015.

82. Morales, M.; Gianotten, V.; Devisscher, M.; Pacheco, D. Hablemos de Tierras; Plural editores, Consultora Sur, Instituto Nacional de Reforma Agraira, Embajada Del Reino de Los Países Bajos: La Paz, Bolivia, 2011.

83. Morales, M.; Naughton-Treves, L.; Suárez, L. Seguridad en la Tenencia de la Tierra e Incentivos para la Conservación de los Bosques; ECOLEX: Quito, Ecuador, 2010.

84. Ríos, S. Proceso de Deforestacion en el Territorio Cacataibo 1995-2010; Instituto del Bien Común: Lima, Peru, 2011.

85. PACTO, AIDESEP. Pueblos Indígenas del Perú: Balance 2014: Sobre el Cumplimiento del Convenio 169 de la OIT; Pacto de Unidad de Organizaciones Indígenas del Perú (PACTO), Asociación Interétnica de Desarrollo de la Selva Peruana (AIDESEP): Lima, Peru, 2015.

86. Pautrat, L. Incidencia de las Políticas Económicas en la Transformación de la Amazonía Peruana en un Paisaje Industrial; Instituto Ética y Desarrollo: Lima, Peru, 2010.

87. Larson, A.M.; Cronkleton, P.; Barry, D.; Pacheco, P. Tenure rights and beyond: Community access to forest resources in Latin America. In CIFOR Occasional Paper; CIFOR: Bogor, Indonesia, 2008; p. 92.

88. Pacheco, P. Smallholders and communities in timber markets: Conditions shaping diverse forms of engagement in Tropical Latin America. Conserv. Soc. 2012, 10, 114-123. [CrossRef]

89. Richards, M.; Wells, A.; Gatto, F.D.; Hermosilla, A.C.; Pommier, D. Impacts of illegality and barriers to legality: A diagnostic analysis of illegal logging in Honduras and Nicaragua. Int. For. Rev. 2003, 5, $282-292$. [CrossRef]

90. L'Roe, J.; Naughton-Treves, L. Effects of a policy-induced income shock on forest-dependent households in the Peruvian Amazon. Ecol. Econ. 2014, 97, 1-9. [CrossRef]

91. Pokorny, B. Smallholders, Forest Management and Rural Development in the Amazon; Earthscan: London, UK, 2013; p. 232.

92. Pacheco, D. An Institutional Analysis of Decentralization and Indigenous Timber Management in Common-Property Forests of Bolivia's Lowlands; Indiana University: Bloomington, IN, USA, 2007.

93. Vega, D.C.; Keenan, R.J. Transaction cost theory of the firm and community forestry enterprises. For. Policy Econ. 2014, 42, 1-7. [CrossRef]

94. Pokorny, B.; de Jong, W.; Godar, J.; Pacheco, P.; Johnson, J. From large to small: Reorienting rural development policies in response to climate change, food security and poverty. For. Policy Econ. 2013, 36, 52-59. [CrossRef]

95. Bottazzi, P.; García, V.R.; Crespo, D.; Stiefel, S.-L.-M.; Galvarro, H.S.; Jacobi, J.; Clavijo, M.; Rist, S. Productive Diversification and Sustainable Use of Complex Social-Ecological Systems: A Comparative Study of Indigenous and Settler Communities in the Bolivian Amazon. Agroecol. Sustain. Food Syst. 2013, 38, 137-164. [CrossRef]

96. Pyhälä, A.; Brown, K.; Adger, W.N. Implications of Livelihood Dependence on Non-Timber Products in Peruvian Amazonia. Ecosystems 2006, 9, 1328-1341. [CrossRef]

97. Stoian, D. Making the best of two worlds: Rural and peri-urban livelihood options sustained by nontimber forest products from the Bolivian Amazon. World Dev. 2005, 33, 1473-1490. [CrossRef]

98. Hermosilla, A.C.; Doornbosch, R.; Lodge, M. The Economics of Illegal Logging and Associated Trade; Organisation for Economic Co-operation and Developmen (OECD): Paris, France, 2007.

99. Pacheco, P.; Barry, D.; Cronkleton, P.; Larson, A. The Role of Informal Institutions in the Use of Forest Resources in Latin America; CIFOR: Bogor, Indonesia, 2008. 
100. Ferroukhi, L. La Gestión Forestal Municipal en América Latina; Center for International Forestry Research, International Development Research Center: Bogor, Indonesia, 2003.

101. Espinoza, O.; Dockry, M.J. Forest Certification in Bolivia: A status report and analysis of stakeholder perspectives. For. Prod. J. 2014, 64, 80-89. [CrossRef]

102. Tacconi, L. Illegal Logging: Law Enforcement, Livelihoods and the Timber Trade; Earthscan: London, UK, 2007; p. 301.

103. Gregersen, H.; Contreras, A. Rethinking Forest Regulations: From Simple Rules to Systems to Promote Best Practices and Compliance; Rights and Resources Initiative: Washington, DC, USA, 2010.

104. Pokorny, B.; de Jong, W. Smallholders and forest landscape transitions: Locally devised development strategies of the tropical Americas. Int. For. Rev. 2015, 17, 1-19. [CrossRef]

105. Cerutti, P.; Lescuyer, G. The Domestic Market for Small-Scale Chainsaw in Cameroon: Present Situation, Opportunities and Challenges; CIFOR: Bogor, Indonesia, 2011.

106. Drigo, I.; Piketty, M.G.; Pena, D.; Sist, P. Cash income from community-based forest management: Lessons from two case studies in the Brazilian Amazon. Bois For. Trop. 2013, 315, 39-49.

107. Molnar, A.; Liddle, M.; Bracer, C.; Khare, A.; White, A.; Bull, J. Community-Based Forest Enterprises in Tropical Forest Countries: Status and Potential; International Tropical Timber Organization, Rights and Resources Initiative, Forest Trends: Washington, DC, USA, 2007.

108. Grogan, J.; Blundell, A.G.; Landis, R.M.; Youatt, A.; Gullison, R.E.; Martinez, M.; Roberto, K.; Lenti, M. Over-harvesting driven by consumer demand leads topopulation decline: Big-leaf mahogany in South America. Conserv. Lett. 2010, 3, 12-20. [CrossRef]

109. Bueren, E.L.V.; Zagt, R.; Savenije, H. Stimulating the Demand for Sustainably Sourced and Licensed Tropical Timber on the European Market; Tropenbos: Wageningen, The Netherlands, 2013.

110. Velásquez, J.; Elgegren, J. Estrategia y Mecanismos Financiaros Nacionales para la Conservación y el usos Sostenible de los Bosques Nacional de Financiamiento Forestal; FAO: Lima, Peru, 2006.

111. ITC. Market Analysis Tools: Enhancing the Transparency of Global Trade and Market Access. Available online: http:/ / legacy.intracen.org/marketanalysis/Default.aspx (accessed on 26 August 2016).

112. Putzel, L.; Padoch, C.; Pinedo-Vasquez, M. The Chinese Timber Trade and the Logging of Peruvian Amazonia. Conserv. Biol. 2008, 22, 1659-1661. [CrossRef] [PubMed]

113. Teye, J.K. Corruption and illegal logging in Ghana. Int. Dev. Plan. Rev. 2013, 35, 1-19. [CrossRef]

114. Waldhoff, P.; Vidal, E. Community loggers attempting to legalize traditional timber harvesting in the Brazilian Amazon: An endless path. For. Policy Econ. 2015, 50, 311-318. [CrossRef]

115. Obidzinski, K.; Kusters, K. Formalizing the logging sector in Indonesia: Historical dynamics and lessons for current policy initiatives. Soc. Nat. Resour. 2015, 28, 530-542. [CrossRef] 